J. Perinat. Med.

$11(1983) 249$

\title{
Congenital meningeal sarcoma - A case report
}

\author{
M. A. T. van Vliet*, B. Bravenboer*, H.C.L.V.Kock*, J.L. J.M.Teepen** \\ * Department of Obstetrics and Gynecology, Maria Hospital Tilburg \\ ** Department of Pathology, St. Elisabeth Hospital Tilburg, Denmark
}

\section{Introduction}

Congenital brain-tumors are rare, and generally diagnosed in the postpartum period. In the majority of cases, these tumors manifest themselves by symptoms related to an increased intracranial pressure and/or by local neurological symptoms. From this and other case reports it is clear that the diagnosis can sometimes be made using ultrasound examinations during the intra-uterine period [14]. The presented case showed a meningeal sarcoma that manifested itself by a progressive, asymmetrical hydrocephalus.

\section{Case report}

A 30-year old gravida II para I was admitted to the obstetrical unit in the 34th week of gestation, because of a large-for-date uterus and fetal abnormalities on ultrasound examination. Her obstetrical history revealed that her first pregnancy was terminated by a transverse lower segment cesarean section because of fetal distress in the 41 th week.

During this, her second pregnancy, there was a period of vaginal bloodloss in the 20th week. The ultrasound examination showed an anatomically completely normal fetus with a distantia biparietalis (DBP) compatible with a pregnancy-duration of 20 weeks. In the 32 nd week the uterus was jugded large-for-date on physical examination. A second abdominal ultrasound examination showed a DBP of $10.5 \mathrm{~cm}$ which is far too large for gestational age. Detailed examination of the fetal head revealed a hydrocephalic asymmetrical ventricular system with bizarre cystic and echogenic regions (Fig. 1). There was a spaceoccupying lesion in the middle cranial fossa. The third echographic examination at 34 weeks showed the fetal head to grow rapidly. The DBP by then was $11.5 \mathrm{~cm}$.

\section{Curriculum vitae}

MARIAN VAN VLIET was born in 1952 in Rotterdam. She obtained her medical degree in 1978. She worked in surgery and internal medicine for two years. Presently she is specializing in gynecology and obstetrics at the Maria Hospital in Tilburg.

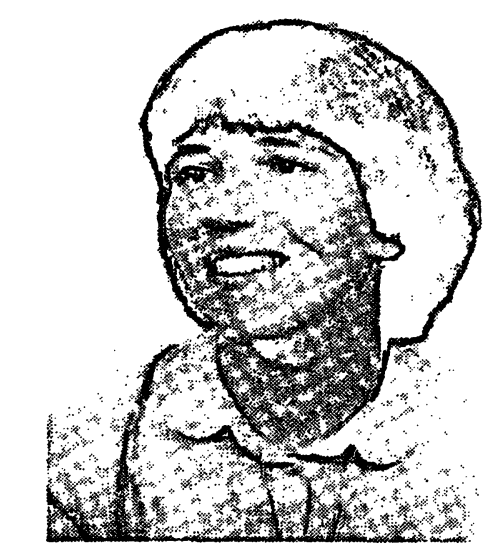

This increase was mainly due to a massive widening of the lateral ventricles. Only a few $\mathrm{mm}$ of the cerebral mantle was left. Since this condition was judged to be incompatible with normal post-partum development, prolongation of this pregnancy did not seem wortwhile. After joint parental consent, pregnancy-termination was decided upon. Because of an unfavourable cervix, oestradiol gel was applied locally for 24 hours [6].

The fetal skull was decompressed by a transabdominal encephalocentesis [10]. Through a 16 gauge, $10 \mathrm{~cm}$ needle a catheter was introduced into the left lateral ventrical under ultrasonic guidance (Fig. 2). However, only a few ml of bloody viscous fluid could be withdrawn. Further manipulation resulted in obtaining just amniotic fluid. Labor was then induced with sulproston intravenously at a dose rate of $2 \gamma$ per minute. After cervical dilation had progressed to $2 \mathrm{~cm}$, encephalocentesis was applied transcervically and 1 liter of bloody cerebrospinal fluid was aspirated through a 24 gauge, $10 \mathrm{~cm}$ needle. Two hours later a fresh stillborn female hydrocephalic infant, weighing $1990 \mathrm{gm}$ was delivered spontaneously (Fig. 3). The histologically normal placenta weighed 465 gram. The postpartum period was uneventful. The parental mourning process was normal. The decision to induce labor, including the unavoidable fetal death during this procedure was neither regretted by the parents nor by the obstetricians. 

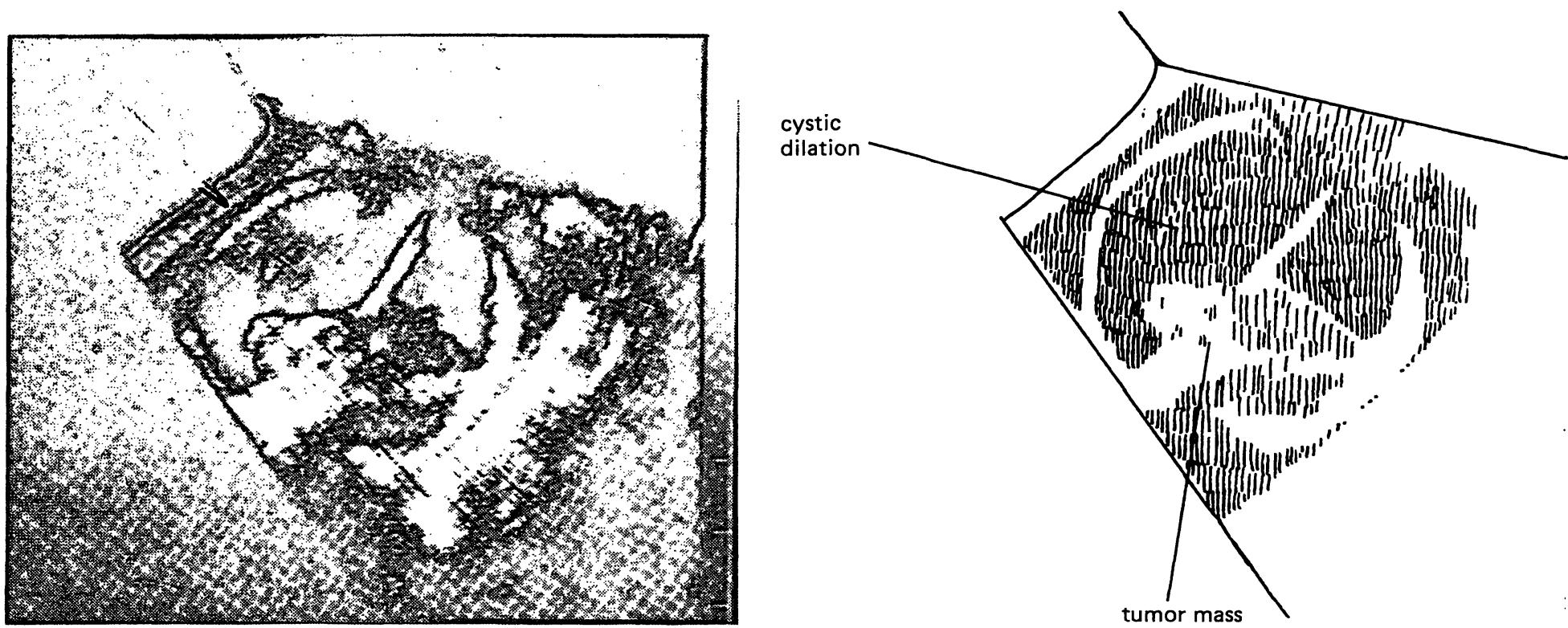

Fig. 1. Tranverse ultrasonic scan of the foetal head, showing an asymmetrical hydrocephalus with bizare cystic and echogenic regions. Gestational age is 32 weeks.

Macroscopic inspection showed a fetal skull far too large for a newborn baby. A tumor was located in the left middle cranial fossa. The tumor was firm on palpation and could be easily dissected from the brain-tissues. In the middle cranial fossa the tumor was attached to the dura mater. The brain weighed 265 mgr. Both lateral ventricles were extremely dilated. The residual cerebral tissue was only a few mm thick. Macroscopic examination of the body organs showed results compatible with those of recent intra-uterine fetal death. Microscopic examination: The fetal brain was fixed with $4 \%$ formaldehyde. Tissueblocks were proceeded for paraffin embedding. The sections were used for routine histology and immunocytochemistry. Some sections were stained with Hema-
toxyline-Eosine, PAS, reticuline according to LAQUESSE, (Fig. 4), Elastica of GIESON, MALLORY's PTAH, CresylViolet, Luxol-fast-blue-PAS and Bodian silver staining. Peroxidase-anti-Peroxidase staining according to STERNBERGER was used to detect glial fibrillary acidic protein, factor VIII and myoglobuline.

The slides revealed a highly cellular tumormass. The tumor cells were very polymorph and fusiforme. The nuclein varied from ovoid to a very irregular shape. Vascularity was marked. The tumor cells were arranged around the vessels. Perivascular, there were many reticuline fibers, as there were in the areas directly related to the dura. The average number of mitosis was 13 per $10 \mathrm{HPF}$ (obj $40 \mathrm{x}$ ) (Fig. 5).
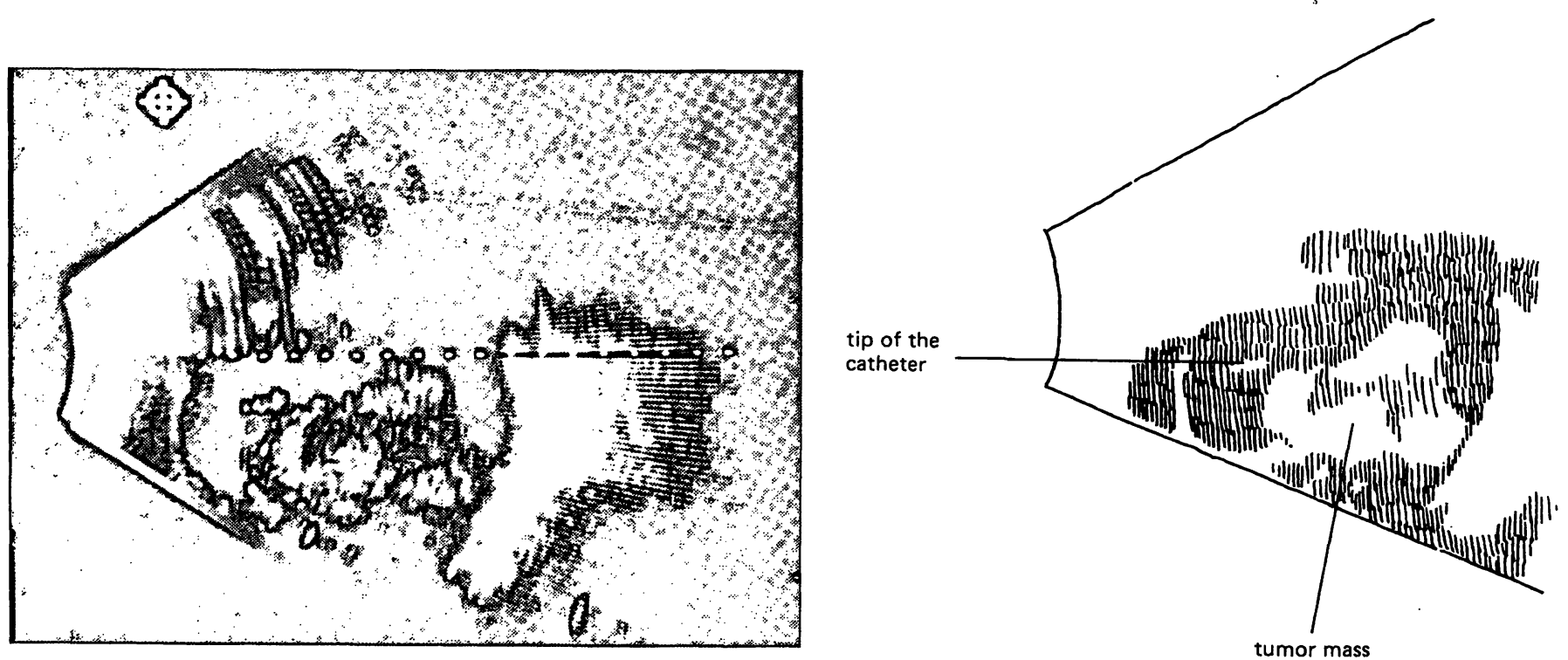

Fig. 2. Localisation of the catheter in the lateral ventricle of the hydrocephalic head. 


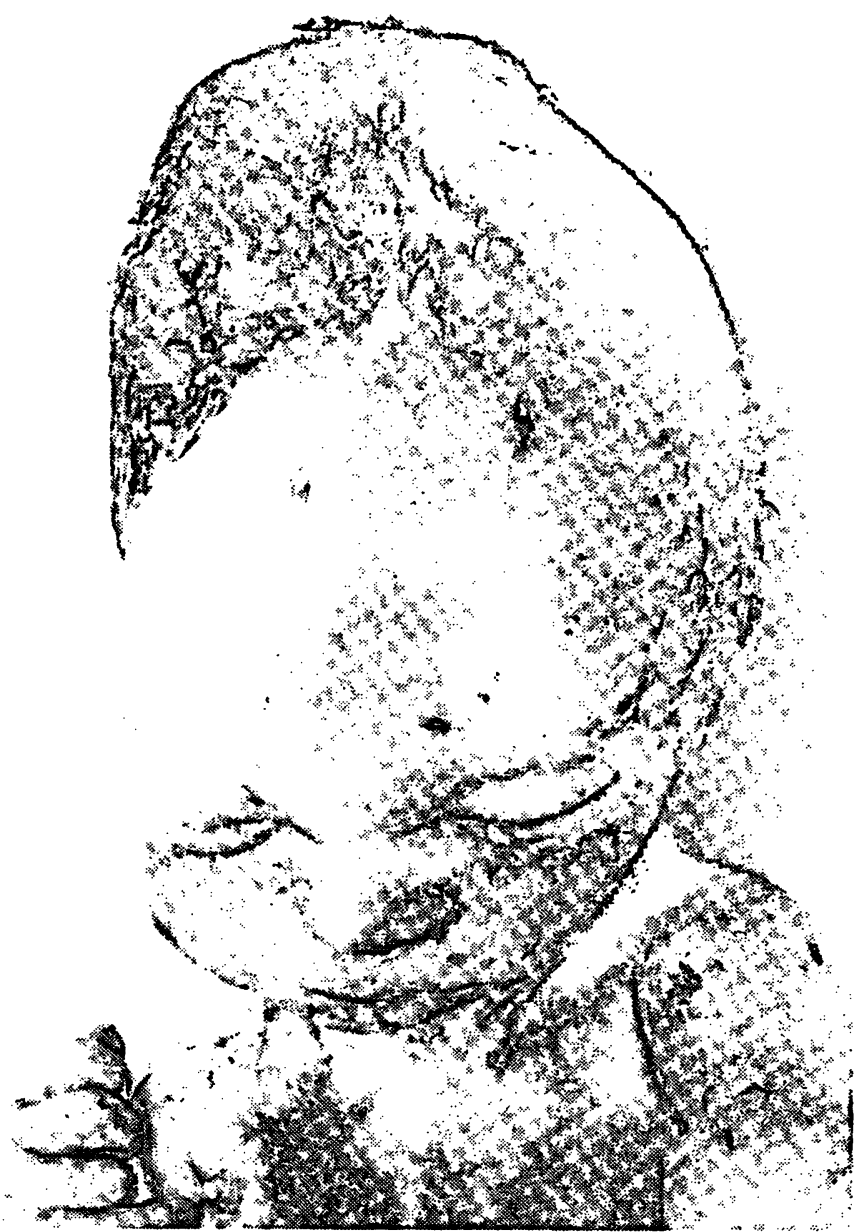

Fig. 3. Picture of the fetal head postpartum.

The tumor did not contain collagen or gliafibers nor neurofibrils or myelinesheets. Staining for factor VIII antibodies and myoglobuline were also negative. NISSL's substance could not be detected.

In conclusion a undifferentiated sarcoma of the dura originating from it in the middle cranial fossa and invading (microscopically) in the brain tissues was diagnosed.

\section{Discussion}

Definitions of the term "congenital brain-tumors" vary among authors. "Congenital" can be interpreted as "derived from embryonal tissue" or as "originating in utero". Three reviews of congenital brain-tumors have been published. In these reviews, WELLS [15] and SOLITARE [13] define three groups of congenital brain-tumors:

1. "definitely congenital" tumors, i.e. presenting or producing symptoms at birth;

2. "probably congenital" tumors, i.e. producing or presenting symptoms within the first week of life;

3. "possibly congenital" tumors, i.e. producing or presenting symptoms within the first month of life.

JELLINGER's and SUNDER-PLASSMANN's [7] classification however included in the "definite congenital" group, tumors manifesting themselves in the first two weeks of life and in the "probably congenital" group, those manifesting themselves in the first year of life. The third group then are tumors detected after the age of one year if the initial symptoms can be traced back to the first year of life.

The real incidence of congenital brain-tumors is unknown. SOLITARE [13] collected 46 case of which 26 were "definitely congenital" (57\%), including only one sarcoma $(2 \%)$. (This case was published earlier by PALMER [11]).

JELLINGER and SUNDER-PLASSMANN [7] described 730 cases of intra-cranial tumors between the age

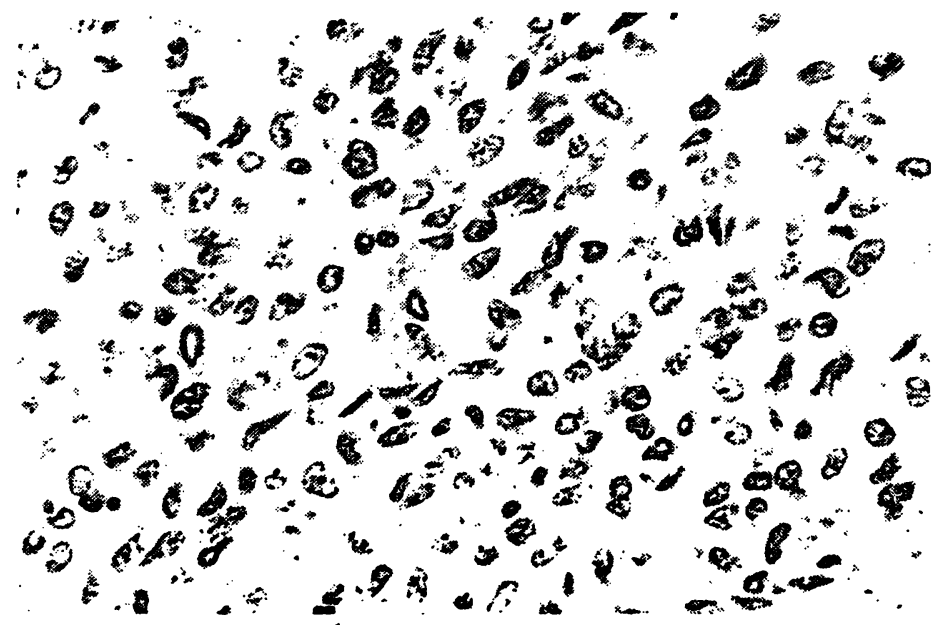

Fig. 5. A highly cellular tumour mass with polymorphic nuclei. There are two mitoses (PTAH : 156) 
of 1 and 16 years. Of the 56 congenital cases $(7.6 \%)$ there were 12 cases classified as "definitely congenital" (1.6\%) including only one case of sarcoma. From the literature they collected another 132 congenital intracranial tumors of which 34 cases were "definitely congenital" (25\%) also including one case of sarcoma. FARWELL [5] mentioned 54 primary intra-cranial neoplasms in infants up to the age of 18 months. Six of these cases were diagnosed antenatally $(11 \%)$. There was no sarcoma in this group.

Most of the congenital tumors are located supratentorial. Clinically a meningeal sarcoma can be easily mistaken for an encephalocele or for a leptomeningeal cyst if located in the occipitial region. The genesis of the tumor is explained as derived from multipotential cells.

Histologically there are three different types:

a. the fibrous fibrosarcoma;

b. the spindle cell type of sarcoma;

c. the undifferentiated or polymorphocellular fibrosarcoma.

In the case of spindle cell and undifferentiated types the prognosis is very poor.

The diagnosis of hydrocephalus during pregnancy can be made by measuring the relationship between the diameters of the ventricle and hemisphere [4-8]. An intracranial tumor should be suspected if there is a rapid progressive asymmetrical hydrocephalus [1]. Once a hydrocephalic fetus is diagnosed, the strategy highly depends on

\section{Summary}

A 30-year-old multigravida woman was admitted to the obstetrical unit in the third trimester of gestation, because of a large-for-date uterus. Repeated ultrasonic examinations over a 2 -week period revealed an increase in biparietal diameter far too large to be normal.

This progressive asymmetrical hydrocephalus was diagnosed as caused by an intracranial space-occupying lesion in the middle cranial fossa. Because of the only minimal thickness of the cerebral cortex prognosis was jugded so poor, that labor was induced. A stillborn female infant was delivered vaginally after an ultrasonically guided transabdominal and later transcervical encephalocentesis. Autopsy revealed hydrocephalus and section through the fixed brain showed that the mentioned mass was an undifferentiated meningeal sarcoma that filled the left middle cranial fossa. Microscopically the sarcoma was invading the brain tissue. the prognosis which is directly related to the thickness of the residual cerebral cortex. Depending on pregnancy-duration one could decide upon an early delivery or an intra-uterine decompression by drainage of the cerebral spinal fluid into the amniotic fluid, especially if the baby is judged to be too premature to be delivered [2].

In our case there was a progressive hydrocephalus; only minimal cerebral cortex was left. The prognosis was judged to be so poor that termination of pregnancy was indicated, irrespective of fetal wellbeing. A vaginal delivery is not contra-indicated after a cesarean section [9]. However, induction of labor with a hydrocephalic fetus seemed to be a serious risk. It was therefore decided upon to induce labor after decompression of the fetal head by transabdominal encephalocentesis under echoscopic guidance [12]. Due to the high viscosity of the hemorrhagic liquid that was drained from the lateral ventricle, decompression of the fetal head was not achieved before the induction of labor could be started, although the catheter was in place (Fig. 2).

Labor was induced 24 hours after the ripening of the unfavourable cervix with oestradiol gel. At $2 \mathrm{~cm}$ cervical dilation, a transcervical encephalocentesis was performed and one liter of highly viscous hemorrhagic fluid withdrawn. Labor progressed then rapidly and there was an easy vaginal delivery. Following this procedure a cesarean section could be avoided. There were no bad feelings about the followed procedure.

Definitions of the term "congenital brain-tumors" vary among authors. "Congenital" can be interpreted as "derived from embryonal tissue" or as "originating in utero". Congenital intracranial neoplasms are very rare. Antenatally intracranial tumors have been reviewed by WELLS, SOLITARE and FARWELL. Only a few cases of congenital brain tumors arising in the meninges have been reported in these reviews.

The genesis of the tumor is explained as derived from multipotential cells. The undifferentiated type of a meningeal sarcoma has a poor prognosis. Most meningeal sarcoma present with progressive hydrocephalus.

The strategy highly depends on the prognosis which is directly related to the type, size and location of the tumor and to the remaining thickness of the cerebral cortex. 
In our case the prognosis was jugded extremely poor. Cesarean section could be avoided by decompression of the fetal head by transabdominal encephalocentesis guided by ultrasound.

Keywords: Brain neoplasms, hydrocephalus, sarcoma.
When antenatal ultrasonography is applied routinely it can be expected that problems concerning the management of fetal abnormalities will present themselves with increasing frequency.

\section{Zusammenfassung}

Kongenitales meningeales Sarkom - Fallbericht

Eine 30jährige Multigravida wurde im letzten Schwangerschaftstrimenon wegen einer abnormen Größenzunahme des Uterus an die geburtshilfliche Abteilung überwiesen. Wiederholte Ultraschalluntersuchungen über einen Zeitraum von 2 Wochen ließen einen viel zu großen biparietalen Schädeldurchmesser erkennen.

Man diagnostizierte einen intrakraniellen raumfordernden Prozeß in der mittleren Schädelgrube als Ursache für diesen progressiven asymmetrischen Hydrozephalus. Da aufgrund der starken Verschmälerung der Hirnrinde die Prognose sehr schlecht war, wurde die Geburt eingeleitet. Unter Ultraschallkontrolle wurde zunächst transabdominal, später transzervikal eine Enzephalozentese vorgenommen und schließlich ein totes Mädchen vaginal geboren.

Bei der Autopsie zeigte sich ein Hydrozephalus. Schnitte durch das fixierte Gehirn ergaben, daß die oben erwähnte Masse ein undifferenziertes meningeales Sarkom darstellte, welches den linken Teil der mittleren Schädelgrube ausfüllte. Mikroskopisch ließ sich nachweisen, daß das Sarkom in das Hirngewebe eingebrochen war.

Der Begriff „kongenitaler Hirntumor" wird von den einzelnen Autoren unterschiedlich definiert. „Kongenital“ kann einmal bedeuten, daß der Hirntumor ,,von embryonalem Gewebe abstammt " oder daß der Tumor, in utero

Schlüsselwörter: Hirnneoplasien, Hydrozephalus, Sarkom. entstanden ist". Kongenitale intrakranielle Neoplasien sind sehr selten. WELLS, SOLITARE und FARWELL berichteten über antenatale intrakranielle Tumoren. In diesen Übersichten werden nur ganz wenige kongenitale Hirntumoren beschrieben, die von den Meningen ausgingen.

Man glaubt, daß der Tumor von multipotenten Zellen abstammt. Der undifferenzierte Typ des meningealen Sarkoms hat eine schlechte Prognose. Die meisten meningealen Sarkome gehen mit einem progressiven Hydrozephalus einher.

Das Vorgehen hängt in hohem Maße von der Prognose, die in direkter Beziehung zur Differenzierung, Größe und Lokalisation des Tumors steht, sowie von der Verschmälerung der Hirnrinde $\mathrm{ab}$.

In unserem Fall war die Prognose extrem schlecht. Durch die mittels Ultraschall kontrollierte transabdominale Enzephalozentese und damit verbundene Dekompression des fetalen Kopfes konnte eine Sectio ceasarea vermieden werden.

Bei routinemäßig durchgeführter antenataler Ultraschalluntersuchung können wir erwarten, daß Probleme, die in Zusammenhang mit fetalen Mißbildungen stehen, immer häufiger erkennbar werden.

\section{Résumé}

Une observation de méningo-sarcome congénital

Une multipare de 30 ans a été hospitalisée dans l'unité obstétricale pendant le troisième trimestre de la grossesse, en raison d'un volume utérin trop important pour le terme. Les échographies répétées pendant 15 jours ont mis en évidence une augmentation du bi-pariétal largement au-dessus de la normale.

A l'origine de cette hydrocéphalie asymétrique progressive a été diagnostiquée une lésion volumineuse intra-cranienne au niveau ventriculaire.

L'accouchement a été déclenché en raison d'un pronostic jugé défavorable du fait de l'extrème minceur du cortex cérébral.

Un enfant mort-né de sexe féminin est né par voie basse après ponction encéphalique sous contrôle échographique d'abord trans-abdominale puis trans-cervicale.

L'autopsie a confirmé 1'hydrocéphalie et les coupes effectuées sur le cerveau fixé ont nontré qu'il s'agissait d'un méningo-sarcome indifférencié comblant le ventricule

latéral gauche. Sur le plan microscopique, le sarcome était invasif.

Selon les auteurs les définitions des «tumeurs cérébrales congénitales» sont variables.

On peut entendre par «congénital» ce qui provient d'un tissu embryonnaire ou ce qui se crée in utéro.

Les néoplasmes intra-craniens congénitaux sont exceptionnels. WELLS, SOLITARE et FARWELL ont étudié de près les tumeurs intra-craniennes anténatales.

Dans ces revues générales seuls quelques cas de tumeurs cérébrales congénitales provenant des méninges ont été rapportés.

L'explication de la genèse de la tumeur est la croissance à partir de cellules multipotentielles.

Le type indifférentié du méningo-sarcome a un pronostic péjoratif. La plupart des méningo-sarcomes s'accompagnent d'une hydrocéphalie progressive.

La stratégie à adopter dépend du pronostic qui est directement lié au type, à la taille et à la localisation de la tumeur ainsi qu'à l'épaisseur restante du cortex cérébral. 
Dans notre observation, le pronostic a été estimé très mauvais. Il fallait éviter une césarienne en décomprimant la tête fœtale grace à une ponction encéphalique transabdominale guidée par ultra-sons.
Lorsque l'on réalise des échographies anténatales en routine, il faut s'attendre à ce que les problèmes concernant la prise en charge d'anqmalies fœtales deviennent de plus en plus fréquents.

Mots-clés: Hydrocéphalie, néoplasmes cérébraux, sarcome.

\section{Bibliography}

[1] ARNSTEIN, L.H., E. BOLDREY, H. C. NAFFZIGER: $A$ case report and survey of brain tumors during the neonatal period. J. Neurosurg. 8 (1951) 315

[2] BIRNHOLZ, J. C., F. D. FRIGOLETTO: Antenatal treatment of hydrocephalus. N. Eng. J. Med.30 (1981) 1021

[3] CHRISTENSEN, E., D. E. LARA: Intracranial sarcomas. J. Neuropathol. Exp. Neurol. 12 (1953) 41

[4] CRADE, M.: Ultrasound demonstration in utero of an intracranial teratoma. JAMA, 247 (1982) 1173

[5] FARWELL, J. R., G. J. DOHRMANN, J. T. FLAN NERY: Intracranial neoplasms in infants. Arch. Neurol. 35 (1978) 533

[6] GORDON, A. J., A. A. CALDER: Oestradiol applied locally to ripen the unfavourable cervix. Lancet II (1977) 1319

[7] JELLINGER, K., M. SUNDER-PLASSMANN : Connatal intracranial tumours. Neuropädiatrie 4 (1973) 46

[8] JOHNSON, M. L., M. G. DUNNE, L. A. MACK: Evaluation of fetal intracranial anatomy by static and real-time ultrasound. J. Clin. Ultrasound 8 (1980) 311

[9] MEIER, P. R., R. P. PORRECO: Trial of labor following cesarean section: A two year experience. Amer.J. Obstet. Gynec. 144 (1982) 671

[10] OSATHANONDH, R., J.C. BIRNHOLZ, A. M. ALTMAN, S. G. DRISCOLL: Ultrasonically guided transabdominal encephalocentesis. J. Reprod. Med. 25 (1980) 125

[11] PALMER, H. D.: Quoted by THIELE, R. L., M. J. DIMMINCK. J. Pediat. 39 (1951) 611

[12] SAMBERG, I., R. GONEN, Z. LEVITAN, M. SHARF: Early vaginal delivery of hydrocephalus after transabdominal encephalocentesis. Int. J. Gynaec. Obstet. 20 (1982) 227

[13] SOLITARE, G. B., M. R. KRIGMAN: Congenital intracranial neoplasm. A case report and review of the literature. J. Neuropath. Exp. Neurol. 23 (1964) 280

[14] DE VORE, G. R., J.C. HOBBINS: Diagnosis of structural abnormalities in the fetus. Clin. Perinatol. 6 (1979) 293

[15] WELLS, H. G.: Occurence and significance of congenital malignant neoplasms. Arch. Path. 30 (1940) 535

Received April 15, 1983. Accepted June 1, 1983.

M.A.T.van Vliet Maria Hospital Tilburg Dr. Deelenlaan 5 5042 AD Tilburg, The Netherlands 